\title{
The Legal Instruments of Family Resilience in Central Java Province (Case Study of Regional Regulations on Family Resilience)
}

\author{
Lita Tyesta ALW', Amalia Diamantika ${ }^{2}$, Amrina Rosyada ${ }^{3}$ \\ \{litatyestalita@yahoo.com ${ }^{1}$, amaliadiamantia.undip@gmail.com ${ }^{2}$, mrosyada92@gmail.com $\left.{ }^{3}\right\}$ \\ 1,2,3 Diponegoro University, Jl.Prof. H. Soedarto, S.H. Tembalang, Tembalang, Kota Semarang, Jawa \\ Tengah, 50275, Indonesia
}

\begin{abstract}
In the perspective of National Resilience, the family is a vanguard in maintaining and strengthening the nation and the state. Family resilience can be defined as the dynamic condition within a family, which consists of tenacities and toughness in facing and solving threats, challenges, obstacles, and disruptions, whether from outside or inside, directly or indirectly, that will harm the harmony, existence, and the integrity of the family. Therefore, we need a new perspective on families. Problems related to family resilience and welfare are huge because the perspectives on the family roles within a state are not wholly included in national policies. Those perspectives were embedded in legal instruments, such as the enactment of Regulation No. 52 the Year 2009 on Population and Family Development.This research aims to compose the Academic Script along with the Regional Regulation Draft that suits the concept of family resilience development as a reference for Provincial Governments. Only West Java and Gorontalo that already had Regional Regulation on Family Resilience Development, even though family resilience is essential to maintain and strengthen the nation's integrity. This research uses the normative juridical method with an approach to regulations, concepts, and comparisons. The expected result is an instrument model of Regional Regulation on Family Resilience Development.
\end{abstract}

Keywords: Family Resilience, Population Policy, Instrumental Models, Family Development

\section{Introduction}

Family resilience can be defined as a dynamic condition within a family that consists of tenacities and toughness in facing and solving threats, challenges, obstacles, and disruptions, whether from outside or inside, directly or indirectly, that will harm the harmony, existence, and the integrity of the family. In the sociological terminology, the family is a group of people related either by marriage, blood, or adoption; that forms a household; in which its members interact and communicate with each other through their roles inside the family, and preserve the common cultures applied by society, or even create their own culture.

Therefore, a new perspective on families is needed. It should be noted that one of the reasons why the problems related to family resilience and welfare are still huge in Indonesia is because the perspectives on the family roles within a state are not wholly included in national policies. It can be validated from several sectors and non-integrated regulations on family resilience. In this case, a new perspective means a perspective which sees family issues as public problems, not private, since the state has its responsibilities to construct family resilience that will develop the state resilience. 
Regulation No. 52 of 2009 on Population and Family Development defines family as "the smallest unit of society, consists of an individual with his or her spouse, or parents with their children, or a father and his children, or a mother and her children."

The same regulation also defines Family Resilience and Welfare as "the condition of a family that consists of tenacities and toughness, as well as physical and material capabilities for living independently and developing himself and his family to live in harmony within the struggles to improve inner and outer happiness."

Furthermore, Regulation No. 52 of 2009 mandates the central and regional governments to establish family development policies through cultivations of family resilience and welfare to support families in doing their role optimally. Using the mandate of Regulation No. 52 of 2009 as the reference, it is evident that regional governments are also responsible for establishing policies related to family resilience development.

Regulation No. 23 of 2014 on Regional Government, in the appendix of the Concern Distribution of Concurrent Government between Central, Provincial, and Municipal, especially letter $\mathrm{H}$ of Women Empowerment and Child Protection. In sub-Concern 3, it is stated that a Province is authorized to:

a. Enhance the quality of family life in actualizing Gender Equality (KG) and Children's Rights at the Provincial and Cross-Municipal level;

b. Strengthen and develop institutions that provide family life quality enhancement service in actualizing KG and Children's Rights with Cross-Municipal work area;

c. Provide services for families in actualizing GE and Children's Rights with CrossMunicipal work area.

While in letter $\mathrm{N}$ of Family Planning and Population Control, in sub-Concern of Prosperous Family, a Province is authorized to:

a. Manage the enforcement of family development program designs through cultivating the family resilience and welfare;

b. Empower and enhance the participation of Provincial community organizations in developing families through cultivating family resilience and welfare.

The explanations above serve as the basis that the government should prioritize family resilience since it is so necessary. As for Regional Officer Organization (OPD) which is authorized to carry out the concerns above, particularly in Central Java Province, is the Women Empowerment, Child Protection, Population, and Family Planning Services.

This research is focused on the problems of how family resilience development policies functions as an effort to strengthen national defense, especially in Central Java Province, and how the ideal legal instrument of family resilience development is carried out in Central Java Province.

The goals of this research are as follows:

a. To understand the regulations and implementations of all related institutions in the field of family resilience development of Central Java.

b. To formulate the necessary efforts in enforcing family resilience development policies through legal instruments.

c. To formulate the adequate legal instruments to develop family resilience, particularly in Central Java.

This research is focused on the regional government policies in composing legal instruments about family resilience development. Right now, the family resilience policies are incredibly urgent to be embedded into legal instruments as an effort to strengthen and maintain nation and state in facing and solving threats, challenges, obstacles, and disruptions, 
whether from outside or inside, directly or indirectly, that will harm the harmony, existence, and the integrity of the family.

This research's result can be used as the material for composing policies for Provincial and Municipal Governments in Central Java, about the formulation of Regional Regulations in developing family resilience. Other than that, hopefully, it also can give feedback to the Regional Governments, whether at the Provincial or Municipal level, in composing Regional Regulations. Therefore, this research has an indirect contribution to the development of science and technology, especially the science of legislation.

\section{Methodology}

The method used for this research is normative juridical that focused on the studies of legal norms in the legislation of family resilience development, whether it is directly or indirectly related to family resilience. Hence, this research can also be said as doctrinal research with prescriptive optic to find the determining rule of law about the juridical rights and obligations of legal subjects and objects in certain social situations[1].

All collected materials have been analyzed using the prescriptive descriptive method, which aims to provide argumentations on this research's result. Those argumentations were used by the writer to give prescription or assessment on how the family resilience development will emerge in the future.

\section{Literature Review}

Regulation No. 23 of 2014 on Regional Government, in the appendix of the Concern Distribution of Concurrent Government between Central, Provincial, and Municipal, especially letter $\mathrm{H}$ of Women Empowerment and Child Protection. In sub-Concern 3, it is stated that a Province is authorized to:

a. Enhance the quality of family life in actualizing Gender Equality (KG) and Children's Rights at the Provincial and Cross-Municipal level;

b. Strengthen and develop institutions that provide family life quality enhancement service in actualizing KG and Children's Rights with Cross-Municipal work area;

c. Provide services for families in actualizing GE and Children's Rights with CrossMunicipal work area.

Meanwhile, letter $\mathrm{N}$ of Family Planning and Population Control, in sub-Concern of Prosperous Family, a Province is authorized to:

a. Manage the enforcement of family development program designs through cultivating the family resilience and welfare;

b. Empower and enhance the participation of Provincial community organizations in developing families through cultivating family resilience and welfare.

The explanations above serve as the basis that the government should prioritize family resilience since it is so necessary. As for Regional Officer Organization (OPD) which is authorized to carry out the concerns above, particularly in Central Java Province, is the Women Empowerment, Child Protection, Population, and Family Planning Services. 


\subsection{Analyzing the family resilience development regulations and policies}

The writer analyzed the Legislations related with the existed conditions, the relations between Constitution and new Regional Regulations with the other Legislations, vertical and horizontal harmonization, and the status of the existed Legislations, including the regulations that had been revoked and invalid, and the ones that are still in force which do not contradict the new Constitution or Regional Regulations. Studies on these Legislations aim to know the condition of the legislations which regulate the substances or matters that are being sought. In these studies, the positions of the new Constitution or Regional Regulations will be discovered. This analysis can depict the synchronization and harmonization degree of the existing Legislations along with the position of the Constitution and Regional Regulations to avoid a clash between them.

Family resilience has been regulated, even though not explicitly, in the 1945 Constitution of the Republic of Indonesia, precisely in:

1. Article 28A: every person shall have the right to live and to defend his/her life and existence.

2. Article 28B paragraph (1): every person shall have the right to establish a family and to procreate based upon lawful marriage.

3. Regulation No. 52 of 2009 on Population and Family Development, although it does not explicitly regulate the family resilience, but it still can be a legal basis for the establishment of Central Java Regional Regulation on the same topic, particularly in Article 47 paragraph (1) which stated that Central and Regional Governments to establish family development policies through cultivations of family resilience and welfare

4. Article 18 paragraph (6) stated that The regional authorities should have the authority to adopt regional regulations and other regulations to implement autonomy and the duty of assistance. Consequently, Regional Government of Central Java refers to the concerns related to family welfare, which also regulate the family resilience as regulated in the Appendix of Regulation No. 23 of 2014, that encourage the establishment the Central Java Regional Regulation concerning the Enforcement of Family Resilience Development.

\subsection{The Ideal Form of Legal Instrument Concerning Family Resilience Development in Central Java}

The preamble of the 1945 Constitution of the Republic of Indonesia stated that: "...therefore, the independence of Indonesia shall be formulated into a constitution of the Republic of Indonesia." The establishment of Government of Indonesia was there because of a purpose: "...protect all the people of Indonesia and all the independence and the land that has been struggled for, and to improve public welfare, to educate the life of the people and to participate toward the establishment of a world order based on freedom, perpetual peace, and social justice."

The Government of Indonesia was established in the structure of the Republic of Indonesia, which based on popular sovereignty. The structure of the Republic of Indonesia was formed based on what was known later as Pancasila, consisted of the belief in the One and Only God, just and civilized humanity, the unity of Indonesia, democratic life led by wisdom of thoughts in deliberation amongst representatives of the people, and achieving social justice for all the people of Indonesia. Pancasila then embodied into the articles in the 
1945 Constitution of the Republic of Indonesia. Later, those articles were used as the basis in the legislation and government regulations instead of law for emergencies. Legislations as the legal norms were elaborated into effective regulations under legislation in the form of government regulations until regional regulations. Therefore, the existence of rechtsidee of Pancasila, Pancasila as the basic principle, Basic Laws (Articles in the 1945 Constitution of the Republic of Indonesia); Legislations/regulations instead of law, Government Regulations under Legislations, until Regional Regulations have functional relations. Regional Regulations are composed as an effort to realize the rechtsidee of Pancasila or Pancasila as the basic principle. They also should put The 1945 Constitution of the Republic of Indonesia as the ultimate legal basis.

Pancasila as the basic principle is the core of thoughts in the Preamble of the 1945 Constitution of the Republic of Indonesia. The Preamble then was explained further in the Explanation of the 1945 Constitution of the Republic of Indonesia. The Explanation stated that "The Constitution brought forth the core of thoughts that lied in its preamble and chapters." These core of thoughts encompass the inner atmosphere of the 1945 Constitution of the Republic of Indonesia. They actualize the rechtsidee that rule the state's fundamental law, whether it is written (Constitution) or not.

"The Constitution brought forth the core of thoughts within its chapters." From that quote, it can be said that Pancasila as the basic principle is the manifestation of legal ideals (rechtsidee), thus making them the ideals of Pancasila itself. Pancasila, as the basic principle, is manifested into Basic Laws in the form of Chapters. These Chapters are then elaborated into the Constitution which can be composed, amended, and revoked easily. The Constitution is a legal norm. The law enforcement regulations as a legal norm are implemented through the Legislations under the Constitution. The Legislations under the Constitution are the practical legal norm, and they can be in the form of Government Regulations until Provincial and Municipal Regional Regulations. Pancasila as the basic principle, Basic Laws and their Chapters, Constitution, Government Regulations, until Provincial and Municipal Regional Regulations. The Chapters within the 1945 Constitution of the Republic of Indonesia or the Basic Laws regulate the human rights as stated in Chapter 27, 28 (especially 28A up to 28J), 29, 30, 31, and 34. These Chapters stated that a family consists of different people with the same rights and obligations.

Philosophically, it can be stated that the Draft of Central Java Regional Regulation on Enforcement of Family Resilience Development is designed to achieve the national goal that based on social justice which beliefs in the One and Only God in order to improve the public welfare and to educate the life of the people based on Pancasila as the nation's ideological foundation.

A comparison study, a family resilience framework can serve as a valuable conceptual to guide prevention and intervention efforts to support and strengthen the vulnerable family in crisis.[2]There is one must understand and recognize the importance of context, as stated by Fraser that resilience emerges from a heterogeneity of the individual and environmental influences that conspire to produce an exceptional performance in the face of significant threats.[3]

\subsection{The sociological influence of society}

Sociologically, the society's influences on the goals of a legislative product will be affected by attitude and perception of society. The absorption process of society's aspirations within the formation of the law will be deeply needed, for the law must accommodate the society's need as the target of the formation of the law itself. Through absorbing the society's aspirations, an 
escape mechanism on problems that may arise will be generated. Hence, absorbing society's aspirations in composing regional regulations on family resilience development is a must.

This sociological basis is a consideration or reason which shows that forming the regional regulations on family resilience development is to fulfill the need of society about family resilience. The empirical facts of the general description on the family resilience in Central Java will be needed for the sociological basis. Human Development Index (HDI) can be utilized as an approach in studying the sociological conditions within the family resilience aspect in Central Java. HDI is aligned with R-IKK that promoted by National Center for Statistics and Women Empowerment and Child Protection Ministry.

Human development is about how we broaden society's option. Human has numerous options and quickly changed every time. Nevertheless, in the field of development, there are only three options, which are to live a long and healthy life, to enjoy the education, and to have accessed on the sources for his needs to maintain a prosperous life. These options are so fundamental and become the only way to access other options. Therefore, it is a must to make sure everyone can obtain these options. Human development also has two sides, like a coin first, the human capabilities shaping, such as the improvement of health, education, and capacity. Second, the use of the capabilities they have, like enjoying their leisure time or being involved in cultural, social, and political agenda. When the scale of human development is imbalanced, instability will likely to occur[4].

According to UNDP, Human Development Index (HDI) measures the accomplishments of human development based on several essential components of quality of life. As the measurement of quality of life, HDI was built through three primary dimensions as follows:

1. A long and healthy life

2. Knowledge

3. A decent standard of living

Those three dimensions have an extensive definition due to many factors. In its first report, UNDP measured the health dimension by using life expectancy at birth, the knowledge dimension was measured by literacy rate, and the decent standard of living was measured by Gross Domestic Product (GDP) per capita.

Masten and Cicchetti summarized salient themes of a system framework into eight principles, and the core of the principles are the following[5]

1. Many interacting systems at multiple levels shapes the function and development of living systems.

2. The capacity for adaptation of a system and its development are dynamic (always changing)

3. Because of interaction and interconnection inherent to living systems, change can spread across domain and levels of function

4. Systems are interdependent

\subsection{Umbrella policy in enforcing family resilience development}

The effort that should be done to establish family resilience development to attain a robust National Resilience is composing the umbrella policy in the form of regional regulations on enforcement of family resilience development. When such Regional Regulation has been implemented, it can become a solid foundation for family resilience, which can be defined as can be defined as the dynamic condition within a family, which consists of tenacities and toughness in facing and solving threats, challenges, obstacles, and disruptions, whether from outside or inside, directly or indirectly, that will harm the harmony, existence, and the integrity of the family. 


\section{Conclusion}

Family resilience has been regulated, even though not explicit, in the 1945 Constitution of the Republic of Indonesia, precisely in:

1. Article 28A: every person shall have the right to live and to defend his/her life and existence.

2. Article 28B paragraph (1): every person shall have the right to establish a family and to procreate based upon lawful marriage

3. Regulation No. 52 of 2009 on Population and Family Development, although it does not explicitly regulate the family resilience, but it still can be a legal basis for the establishment of Central Java Regional Regulation on the same topic, particularly in Article 47 paragraph (1) which stated that Central and Regional Governments to establish family development policies through cultivations of family resilience and welfare

4. Article 18 paragraph (6) stated that The regional authorities should have the authority to adopt regional regulations and other regulations to implement autonomy and the duty of assistance. Consequently, Regional Government of Central Java refers to the concerns related to family welfare, which also regulate the family resilience as regulated in the Appendix of Regulation No. 23 of 2014, that encourage the establishment the Central Java Regional Regulation concerning the Enforcement of Family Resilience Development.

The effort that should be done to establish family resilience development to attain a robust National Resilience is composing the umbrella policy in the form of regional regulations on enforcement of family resilience development. When such Regional Regulation has been implemented, it can become a solid foundation for family resilience, which can be defined as can be defined as the dynamic condition within a family, which consists of tenacities and toughness in facing and solving threats, challenges, obstacles, and disruptions, whether from outside or inside, directly or indirectly, that will harm the harmony, existence, and the integrity of the family.

\section{References}

[1] M. van Hecke, Methodologies of Legal Research: Which kind of Method for What kind of Discipline? London: Hart Publishing, 2011.

[2] F. Walsh, "A family resilience framework: Innovative practice applications," Family Relations. 2002.

[3] L. M. Hooper, "Individual and Family Resilience: Definitions, Research, and Frameworks Relevant for All Counselors.," Alabama Couns. Assoc. J., 2008.

[4] Badan Pusat Statistik (Center Statistic Beaurue) Indonesia, "Indeks Pembangunan Manusia 2014, Metode Baru," Jakarta, 2015.

[5] A. S. Masten, "Resilience Theory and Research on Children and Families: Past, Present, and Promise," Journal of Family Theory and Review. 2018. 